\title{
The procurement of food on board liner ships: the role of the international labor organization
}

Yui-yip Lau ${ }^{1,2,3^{*}}$ and Tsz Leung Yip ${ }^{4}$

\author{
* Correspondence: \\ yylau@hkcc-polyu.edu.hk \\ 'Division of Business, Hong Kong \\ Community College, The Hong \\ Kong Polytechnic University, Hong \\ Kong, China \\ ${ }^{2}$ Transport Institute, Asper School of \\ Business, University of Manitoba, \\ Winnipeg MB R3T 5V4 Canada \\ Full list of author information is \\ available at the end of the article
}

\begin{abstract}
Food is important for liner shipping companies (LSCs) in their efforts to support daily lives and fulfil seafarer demand. Food issues are addressed in the International Labour Organization's (ILO's) Food and Catering (Ships' Crews) Convention 1946 (No. 68), amended 2006. Moreover, the enforcement of the Maritime Labour Convention (MLC) Regulations and Code appears to have ensured that seafarers have hygienic conditions and that good quality food and drinking water are provided. The MLC aims to meet all current standards of international maritime labour conventions and recommendations, and comply with the fundamental principles found in other international labour conventions. Yet despite these efforts, food issues require greater attention, as maintaining the food supply chain is a dynamic and difficult task. To identify strategies for improving the procurement of food for ships, this paper illustrates how to facilitate the food supply for shipping lines and further evaluate the associated supply chain. Advanced technology, comprehensive procurement procedures, qualified personnel, extensive outbound logistics (i.e., distribution) networks and sound training programmes on food quality and safety are critical elements in the food supply chain, and will enhance the quality of food for seafarers.
\end{abstract}

Keywords: Food supply chain, Liner shipping, Supply chain performance indicators, ILO convention

\section{Introduction}

Liner shipping companies' (LSCs) demand for a wider range of high quality food for seafarers has increased in the last decade given the importance of safe, fresh and nutritious food to support the daily lives of seafarers (McWilliams, 2008). Due to the long duration of maritime voyages, the procurement and storage of food on board ships has always been a significant challenge, most notably for ships sailing in developing countries or regions. Seafarers face an increased risk of developing chronic diseases because of malnutrition (Officer of the Watch, 2012). Improvements in food management to maintain food quality and safety have been proposed (Muller and Steinhart, 2006; Jacques and Peter, 2007; Keiser et al., 2008).

Ocean-going seafarers live on board vessels in confined environments for long periods, and life at sea imposes unique stresses on the human body. Ocean voyages can influence the human immune system, leading to various illnesses (Lu et al., 2010;

(c) The Author(s). 2017 Open Access This article is distributed under the terms of the Creative Commons Attribution 4.0 International License (http://creativecommons.org/licenses/by/4.0/), which permits unrestricted use, distribution, and reproduction in any medium, provided you give appropriate credit to the original author(s) and the source, provide a link to the Creative Commons license, and indicate if changes were made. 
Myznikov et al., 2000; Protasov et al., 1996), severe temperature changes and poor diet structure can lead to subtle changes in physiological and psychological functions (Lu et al., 2010), and the lack of physical exercise can contribute to ischemic heart disease (IHD).

The maritime industry has paid greater attention to monitoring food and catering for seafarers in the last decade. Such food issues are addressed by the International Labour Organization's (ILO's) Food and Catering (Ships' Crews) Convention 1946 (No. 68) and the Certification of Ships' Cooks Convention 1946 (No. 69), amended in 2006 in Geneva. The Guidelines on the Training of Ships' Cooks (2014, pp. 19) presents three main guidelines for the training of ships' cooks: (An \& Noh, 2009) food and drinking water of suitable quantity, nutritional value, quality and variety must be supplied with regard to the number of seafarers on board, their religious requirements and cultural practices, and the duration and nature of the voyage; (Byran \& Brian, 1999) the organisation and equipment of the catering department must permit the provision to the seafarers of adequate, varied and nutritious meals prepared and served in hygienic conditions; and (Campbell et al., 2002) catering staff must be properly trained or instructed for their positions. These guidelines aim to give practical information that can be included in national laws and other measures to implement them (ILO, 2014).

The ILO stated that 'the basic aims of the MLC, 2006, are to ensure comprehensive worldwide protection of the rights of seafarers and to establish a level playing field for member States and ship owners committed to providing decent working and living conditions for seafarers' (ILO, 2014, pp. 6). Indeed the ILO (1999, page 4) introduced a new enforcement mechanism to ensure that seafarers' living and working conditions meet its requirements of 'decent work ... in conditions of freedom, equity, security and human dignity'. Along with certain other proposals, the MLC protects 1.5 million seafarers around the world by ensuring minimum and consistent living and working conditions (Milde, 2011, ILO, 2014).

In LSCs, the food supply chain involves sourcing food through multiple suppliers and delivering the appropriate amount of food to seafarers on board. One of the major functions of the purchasing departments of the LSCs is to procure food from all over the world to fleet vessels so they can maintain smooth operations on board. The food supply must be flexible, punctual, responsive and quick to formulate and implement different sourcing strategies. The food supply chain thus has become a dynamic, extensive and ever-changing entity, and attempting to cover such a broad subject is a difficult task. Yet although many research studies have focused on major ILO issues such as social and labour rights for seafarers (McConnell, 2011), maritime security (Doumbia-Henry, 2003) and policy for the seafaring labour market (Lobrigo and Pawlik, 2015), a collection of 294 academic papers from 1967 to 2013 rarely discussed the food supply chain in relation to ships.

The remainder of this paper is organised as follows. Section 2 provides a review of the literature on the food supply chain for ships. In Section 3, a value chain analysis of the food supply chain for ships is conducted, and in Section 4 a case study is presented to evaluate food supply chain performance. Section 5 examines the shortcomings of the food supply chain and in Section 6 we draw our conclusions and discuss implications for future research. 


\section{Literature review}

\section{The food supply chain on board}

The food supply chain has several key characteristics, including shelf life constraints for raw materials and perishable products, a long production throughput time, seasonality of production, the necessity of conditioned transportation and storage and safety concerns (Kuo and Chen, 2010). The food industry's general overview of food supply chains is constantly changing because the business environment is dynamic (Dani and Deep, 2010; Iijima et al., 1996; Kuo and Chen, 2010; Van Der Vorst and Beulens, 1999). Any changes in distance, time or temperature in the chain can significantly increase costs or disrupt the net present value of the activities and their added value in the supply chain (Verbic, 2006). Roth et al. (2008) discussed three main trends affecting food supply chains in contemporary business environments pertaining to commoditisation, consolidation and globalisation. Commoditisation distinguishes between food products as either commodities or value added. Consolidation refers to food supply chain members combining food categories and the levels of the supply chain in pursuit of higher margins. Globalisation leads not only to the global sourcing of raw materials but also to post-production activities such as the storage, transport, distribution and retail of final food products and their export and import (Kuo and Chen, 2010). The global nature of the food supply chain is vividly depicted by the sourcing of ingredients from different countries.

Perhaps the most significant aspect of the food supply chain problem is mainly facing food degradation. In broad terms, both intrinsic and extrinsic factors determine food degradation rates (Robert et al., 1998). The relevant intrinsic factors are the sugar content, salt content and $\mathrm{pH}$ properties and product nature of the food in question. The extrinsic factors include environmental factors such as humidity, the presence of gases and temperature (Byran and Brian, 1999; Mohsen, 2005; Robert et al., 1998). It is essential to handle these factors efficiently and effectively to slow the degradation rate. The pickling and salting of food are common approaches to lengthening shelf life, thus controlling the more easily influenced intrinsic factors (Robert et al., 1998), but these methods are not optimal due to the permanent changes they cause in the structure and taste of food. The food life cycle is short, and the rate of degradation is still easily affected by biological factors and environmental conditions (Milde, 2011). To protect the integrity of food and reduce the growth rate of spoilage microorganisms, it is important to design flexible, responsive and rapid food supply chains by removing unnecessary activities, creating information transparency and increasing coordination of operations (Kuo and Chen, 2010; Kurt Salmon Associates, 1993; Rodrigue and Craig, 2009). Thus, this research paper focuses on managing the extrinsic factors to control the quality of food while maintaining its structure and taste.

\section{Value chain analysis of the food supply chain to ships}

In this paper, a value chain analysis was adopted as the fundamental theoretical framework to evaluate the food supply chain to ships. Value chain analysis is a powerful tool for managers wanting to identify key activities and design strategic planning within the firm. We use it to discuss competitive strategies and value to the customer in detail. The competitive strategies of firms were evident by their 
ability to perform better than their competitors on crucial activities along the food supply chain. The food supply chains thus maximise value creation while minimising costs (Porter, 1985).

Porter (1985) was the first to discuss the concept of the value chain in his book "Competitive Advantage: Creating and Sustaining Superior Performance" Origination in business management research, it has been widely adopted other areas over the last three decades. According to Porter (1990, page 41), firms' activities can be broken down into a sequence of activities called a value chain, 'an interdependent system or network of activities connected by linkages'. When the system is managed carefully, the linkage can be a vital source of competitive advantage (Pathania-Jian, 2001). According to Lynch (2003), value chain analysis is divided into two areas. The first discusses the value chain links concerning the value of the organisations' activities within key functional parts. The second assesses the contribution of each part in the overall added value of the business. In value chain analysis, the firm is divided into primary and support activities. Primary activities are related to production, and support activities are concerned with the background necessary for the efficiency and effectiveness of the firm.

By reviewing both primary and support activities in the value chain, it was found that most elements determine the performance of food supply chains. In primary activities, inbound logistics, operations and outbound logistics enhance food supply chain operations. Inbound logistics are concerned with receiving the food or materials from suppliers, storing these externally sourced food or materials and handling them within the firms. Operations are concerned with the production or value added of products and services in departments within the firm. Outbound logistics are concerned with distributing the food to the final customer. In service industries, firms regularly monitor food supply chain operations, and remedial action is taken in the event of non-conformance. Marketing and sales preserve the required quantity and quality of the food in the available market to maintain stability in cold chains (Verbic, 2006).

In terms of support activities, procurement, technology development, and firm infrastructure are essential elements in facilitating the operations of the food supply chain. Procurement handles the purchase of food or materials that are necessary for the food supply chain's operations. Efficient procurement departments can obtain the highest quality food or materials at the lowest costs. Technology development is concerned with the technological innovation, training and knowledge that is crucial for food supply chains to upgrade their capacities. In terms of firm infrastructure, firms implement corporate strategy to support overall food supply chain operations. Human resource management involves recruiting qualified persons to manage the cool chain process so that food can be produced, stored and distributed under the most hygienic and controlled conditions possible. The ultimate objective is to provide customers with assurance and confidence.

The two main issues facing ships' food supply chains can be categorised as intrinsically relating to food and more broadly associated with the supply chain. Food quality, food types and beverage quality are the key food issues, whereas reliability, responsiveness and assurance are the main aspects of concern in relation to the supply chain. Taken together, these issues can be summarised as follows. 
(1)Food quality: refers to the intrinsic food quality such as menu, taste and freshness and extrinsic considerations pertaining to sanitation, presentation and temperature (An and Noh, 2009). These determine the totality of the features and characteristics of a product or service that bear on its ability to satisfy stated or implied needs (ISO 8402).

(2)Food types: refers to the kinds of food that a shipping line provides to seafarers, generally divided into bond and provisions. Bond includes cigarettes, alcohol, chocolate and snacks, whereas provisions include biscuits, rice and flour.

(3) Beverage quality: refers to the degree to which seafarers are satisfied with the beverages provided on board such as alcohol, water, tea and juice.

(4) Reliability: refers to the ability to provide the promised food accurately and credibly.

(5) Responsiveness: refers to the ability to provide food promptly to seafarers.

(6) Assurance: refers to the temperament or quality of employees to inspire reliability, belief, courtesy and knowledge (An and Noh, 2009).

Food and supply chain issues affect seafarers' health, which in turn affects their productivity. High-quality seafarer meals and a capable agri-food supply chain should thus be maintained to provide better health for ocean-going seamen. Seafarers' overall satisfaction, based on their perceptions of food quality and performance, and loyalty, or their continued desire to provide service to a shipping line, a key outcomes of an effective supply chain for ships. Thus, meal service should be planned carefully to satisfy seafarers' expectations from the selection of the menu to efficient and reliable service.

We analyse the interactions between food suppliers and LSCs (see Fig. 1) based on a synthesis of previous work on value chains (Porter 1985). The research team adopted the value chain analysis as a fundamental theoretical framework to forge possible

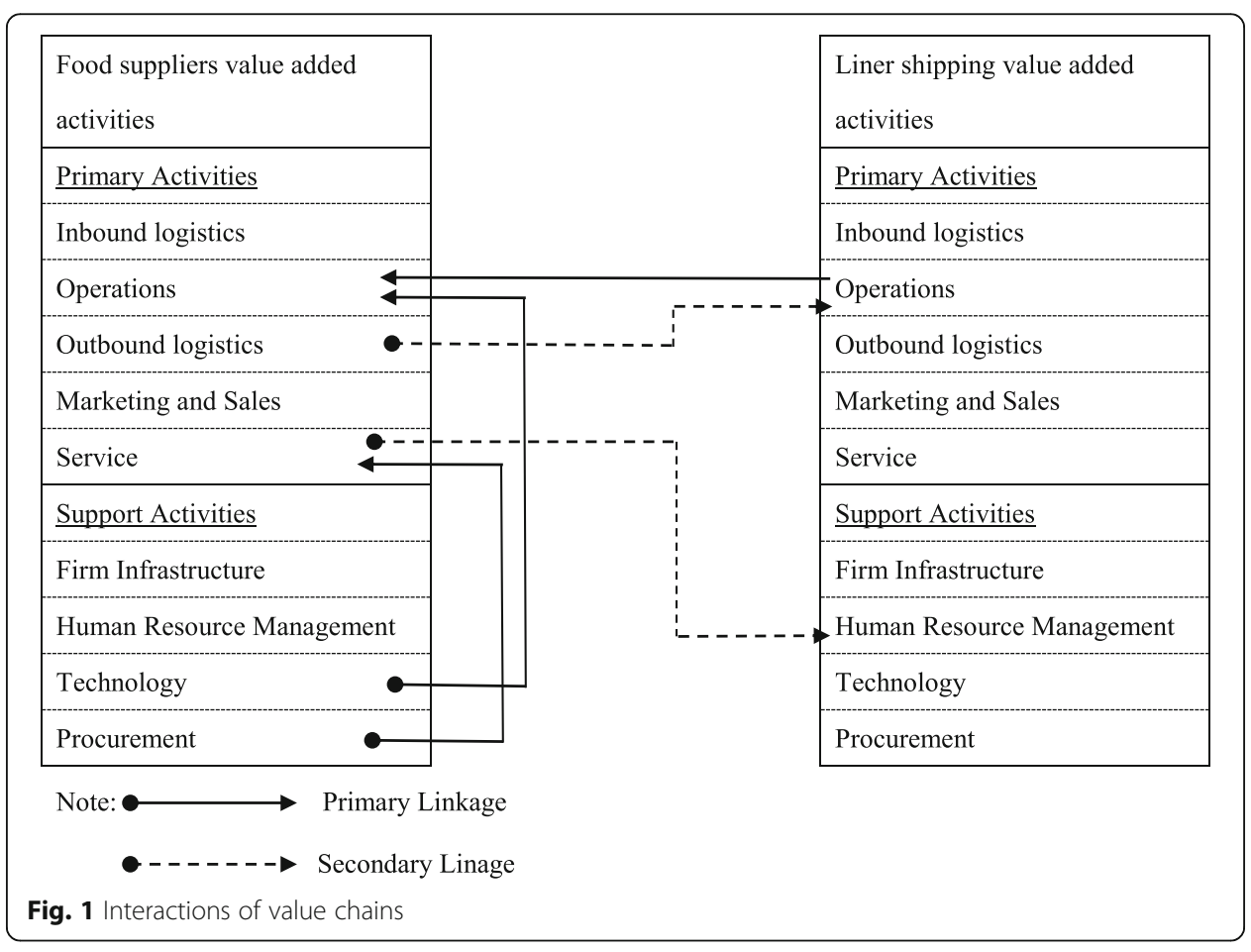


linkages between food suppliers and LSCs. The framework has strong theoretical underpinnings and shows that food suppliers and LSCs are closely interrelated.

Figure 1 presents the elements in which value creation takes place within the food suppliers and LSCs. The performance of value chain operations is influenced by a range of primary activities (i.e., inbound logistics, operations, outbound logistics, marketing and sales, service) and support activities (i.e., firm infrastructure, human resource management, technology, procurement). For food suppliers, primary activities and support activities directly affect the performance of the LSCs' value chain operations. In LSCs, primary activities influence the performance of food suppliers' value chain operations. The ultimate objective is to maximise value creation while minimising costs in the food supply chains. In the figure, solid lines denote primary linkages and dotted lines denote secondary linkages.

From food suppliers to liner shipping companies (dotted lines):

1. Outbound logistics are critical to operations (i.e., ship schedules). Operational processes must meet or exceed international safety and hygiene standards. Food suppliers must distribute the food products not only freshly and safely but in a timely manner to meet LSCs' schedules and the turnaround times of ships in port. Otherwise, voyages will be delayed and which would be detrimental to the customer service levels of LSCs.

2. Streamlined and efficient procurement procedures ensure that ships obtain the best quality raw materials and other production requirements in the timeliest manner. Good service by food suppliers is critical to the satisfaction of seafarers, which is a key issue in human resource management. Human resource departments recruit qualified personnel to operate the food supply chain while designing and delivering comprehensive training courses to increase their staff members' knowledge of food quality and safety. This ensures that food quality and performance can be sustained at satisfactory levels, and that seafarers' satisfaction can be increased.

From liner shipping companies to food suppliers (solid lines):

Liner shipping companies' operations (i.e., ship schedules) place constraints on food suppliers' operations. The inventory levels in ships are low because there is limited space for food storage on board. Furthermore, the turnaround time of ships in port is reduced and voyage time is increased due to slow streaming. Thus, food suppliers frequently fail to meet ship schedules and requests.

\section{Case study}

To verify our analysis framework and results, a questionnaire survey was conducted between February to July 2017. We sent surveys to 14 target interviewees, 11 of whom completed the survey, yielding a $78.5 \%$ response rate. Because of confidentiality agreements, all details of the interviewees are excluded in our reporting. The target interviewees held supervisory and managerial jobs in the maritime industry pertaining to ship management, marine insurance, government body, ship brokerage, terminals, liner firms and ship agencies. The range of their working experience in the maritime industry is from 4 to 50 years. Hence, they are qualified to provide insight into our study. The profiles of the interviewees are summarised in Table 1. 
Table 1 Questionnaire survey - list of interviewees

\begin{tabular}{|c|c|c|c|c|}
\hline Interviewee & Position & $\begin{array}{l}\text { The nature of } \\
\text { company }\end{array}$ & $\begin{array}{l}\text { The working } \\
\text { department }\end{array}$ & $\begin{array}{l}\text { Working years in the } \\
\text { maritime industry }\end{array}$ \\
\hline 1 & Director and captain & Ship broker & Proprietor & 50 \\
\hline 2 & Vessel Planner & Liner firm & Operations & 4 \\
\hline 3 & Assistant manager & Ship agent & Documentation & 6 \\
\hline 4 & Captain & Government & Education & 43 \\
\hline 5 & Claims executive & Marine insurance & Claims & 7 \\
\hline 6 & Manager & Ship management & Chartering & 11 \\
\hline 7 & Manager & Terminal & Sales and Marketing & 15 \\
\hline 8 & Senior quality assurance officer & Liner firm & Quality Assurance & 10 years \\
\hline 9 & Manager & Ship management & Chartering & 10 years \\
\hline 10 & Captain & Ship agent & Technical & 40 years \\
\hline 11 & Captain & Marine insurance & Marine insurance & 25 years \\
\hline
\end{tabular}

The questionnaire survey consists of two main sections. Section A collects demographic details of interviewees. Section B is intended to provide insights into interviewees' perceptions on the role of the ILO in improving the food supply chain on board by using a 5 -point Likert-style scale (i.e., 1 = strongly disagree; 2 = disagree; 3 = neutral; 4 = agree; 5 = strongly agree). The results were used to verify the value chain analysis and the discussion of policy implications. The interview questions and results are listed in Table 2 .

According to the survey results, respondents agree that food suppliers' advanced technology adds value to their food supply chain operations (3.73). The survey respondents also stated that food suppliers' procurement procedures are critical to the food supply chain (4.09). Food suppliers' tight procurement procedures enhance their service level. Hence, procurement activities and service are closely linked in food suppliers' value chain. In addition, interviewees stated that it is very important for LSCs to establish human resources departments to provide training to staff on food quality and safety (3.73). Most interviewees stated that good food supplier service is critical to the satisfaction of seafarers (4.18). Accordingly, food suppliers provide professional service to LSCs on food supply chain operations. Therefore, human resource management is closely related to service within a value chain between food suppliers and LSCs. The survey respondents also reported that having qualified personnel is critical to operating and managing the food supply chain between food suppliers and LSCs (4.09). The operations between food suppliers and LSCs are closely interrelated in value chains. Finally, survey respondents reported that food suppliers' outbound logistics (i.e., distribution) are critical to LSCs' food supply operations (3.82). Thus, food supplier outbound logistics have a direct linkage with LSC operations in the value chain.

In practice, LSCs source food from different suppliers. It is difficult for LSCs to manage procurement operations and build relations with suppliers. External environmental factors pertaining to ports of call, the nature of commodities and climate affect the quality and reliability of food supplies. Based on these factors, we design food supply chains for ships in Fig. 2. Food suppliers have multiple suppliers based on the nature of the commodities. However, LSCs usually appoint only a single supplier to provide food to seafarers. This single supplier consolidates the food and 
Table 2 Questionnaire survey - summary of survey results

\begin{tabular}{|c|c|c|}
\hline Survey question & $\begin{array}{l}\text { Average score (Range of } \\
\text { score) }\end{array}$ & Comment \\
\hline \multicolumn{3}{|l|}{ Policy implications } \\
\hline $\begin{array}{l}\text { ILO Food and Catering (Ships' Crews) Convention and the Certification } \\
\text { of Ships' Cooks Convention maintain all up-to-date standards of existing } \\
\text { international maritime labour Conventions and recommendations }\end{array}$ & $3.36(2-5)$ & Agree \\
\hline $\begin{array}{l}\text { Seafarers have access to good quality food and drinking water provided } \\
\text { regulated hygienic conditions }\end{array}$ & $4.00(3-5)$ & Agree \\
\hline $\begin{array}{l}\text { The key information (i.e., ILO Regulations and the Code) is public access } \\
\text { so that the maritime stakeholders are able to obtain it anywhere }\end{array}$ & $3.91(3-5)$ & Agree \\
\hline $\begin{array}{l}\text { The seafarers' food and catering is deemed as more a problem to solve } \\
\text { instead of an opportunity to innovate. }\end{array}$ & $3.18(2-5)$ & Agree \\
\hline $\begin{array}{l}\text { There is misalignment when implementing and promulgating the } \\
\text { seafarers' food and catering instruments to different global regions. }\end{array}$ & $3.27(2-5)$ & Agree \\
\hline $\begin{array}{l}\text { The attitude of ship operators to seafarers' food is actively participated } \\
\text { in improving seafarer working condition. }\end{array}$ & $3.91(2-5)$ & Agree \\
\hline $\begin{array}{l}\text { The poor health conditions lead to adversely effect on seafarers' } \\
\text { performance and behaviour. }\end{array}$ & $4.45(3-5)$ & Agree \\
\hline $\begin{array}{l}\text { ILO Regulation and Code could not encourage all countries to follow or } \\
\text { adopt. }\end{array}$ & $2.82(2-4)$ & Disagree \\
\hline $\begin{array}{l}\text { Flag of convenience intensified seafarers working under unacceptable } \\
\text { conditions. }\end{array}$ & $2.36(1-3)$ & Disagree \\
\hline $\begin{array}{l}\text { Seafarers could perceive significant improvement on working conditions } \\
\text { under seafarer's trade union. }\end{array}$ & $3.73(3-5)$ & Agree \\
\hline \multicolumn{3}{|l|}{ Value chain analysis } \\
\hline Technology adds value to food supply chain operations. & $3.73(2-5)$ & Agree \\
\hline Outbound logistics (i.e., distribution) is critical to food supply operations. & $3.82(3-5)$ & Agree \\
\hline Good service of food supplier is critical to the satisfactory of seafarer. & $4.18(3-5)$ & Agree \\
\hline Procurement procedures are critical to food supply chains. & $4.09(3-5)$ & Agree \\
\hline $\begin{array}{l}\text { Qualified personnel are critical to operate and manage food supply } \\
\text { chain. }\end{array}$ & $4.09(3-5)$ & Agree \\
\hline $\begin{array}{l}\text { Human resources department provides training to staff on food quality } \\
\text { and safety }\end{array}$ & $3.73(3-5)$ & Agree \\
\hline
\end{tabular}

In this study, the 5 -scale Likert-style score scale was used in the survey questionnaire (i.e., $1=$ strongly disagree;

2 = disagree; 3 = neutral; 4 = agree; 5 = strongly agree)

distributes it to the ships. Lau and Yip (2010) stated that the key advantages of single sourcing are that it:

- Develops long-term relationships between LSCs and food suppliers,

- Allows both parties to work together more closely,

- Encourages stronger commitment by the supplier to invest in facilities or information technology and share real-time information,

- Gets suppliers involved early in the product development stage and thus controls the upstream supply chain as quickly as possible,

- Enhances resource allocation in the core business,

- Results in lower purchase costs due to a much higher volume from a single supplier, and

- Makes vendor management easier.

Lau and Yip (2010) also commented that the potential drawbacks of single sourcing include the following: 


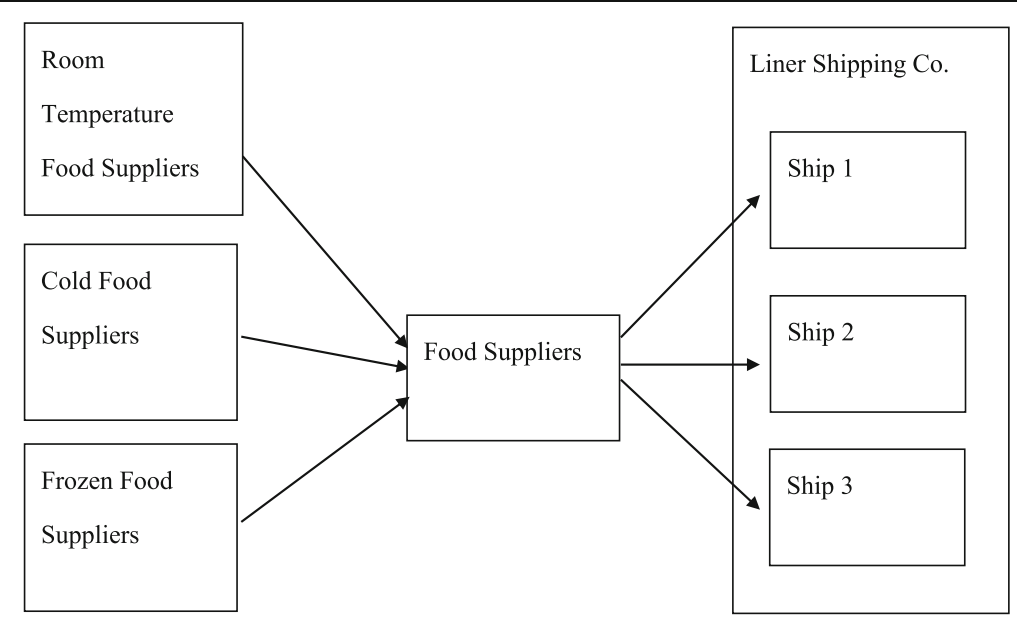

Fig. 2 Food supply chains to ships

- Maintains relationship with supplier is difficult,

- Gets supplier for price negotiation and improve the performance is difficult because of less competition among suppliers,

- Creates a higher chance of supply interruption, especially for asset specific products, and

- Increases vulnerability of product quality and service.

From LSCs' perspective, there are three major categories of the food supply chain according to temperature control and monitoring: room temperature food, cold food, and frozen food. Each type of food has different requirements in the food supply chain. Room temperature food includes water, biscuits, rice and flour in addition to foods that respond slowly to temperature changes. The temperature for these foods must be maintained at $18{ }^{\circ} \mathrm{C}$. Cold food includes vegetables and fruit and other items that are highly responsive to temperature changes. The temperature for such foods must be maintained at $0{ }^{\circ} \mathrm{C}$ to $+7{ }^{\circ} \mathrm{C}$. Frozen food includes meat and fish in addition to foods that respond slowly to temperature changes. The temperature for such foods must be maintained at $-18{ }^{\circ} \mathrm{C}$. In the transportation of frozen food, the fresh air ventilators must always be closed and the humidity indicator should be in the OFF position. Temperature is an important parameter in food safety and quality (Montanari, 2008; Ovca and Jevsnik, 2009). During the logistics process, any change in time-distance or temperature may create spoilage or loss of flavour. Thus, temperature needs to be continuously and carefully controlled and monitored at each stage of the food supply chain with adequate control systems, correct placement of temperature sensors and efficient insulation. All perishable products are required to be delivered by a refrigerated loading dock to minimise the increase in product temperature during loading and unloading and to avoid the entrance of moist or warm ambient air.

For a food supplier (Fig. 1), (An \& Noh, 2009) cold technologies are critical to cool chain operations and (Byran \& Brian, 1999) the procurement of cold facilities is critical for service to LSCs. Currently, food suppliers incorporate multi-temperature measuring devices (e.g., melting point, thermal expansion, emissivity, diffusion, solidification temperature), viscoelastic properties or chemical reactions (e.g., electrochemical 
corrosion, enzymatic reactions, and polymerisation) and mobile technology to ensure food quality and safety in the cold chain. The emergence of radio frequency identification (RFID) is a common type of mobile technology. RFID can be used to track, identify and recall products in the food supply chain. RFID includes various functions such as real-time information, real-time tracing, order tracing and temperature monitoring (Kuo and Chen, 2010). It can ensure that perishable products with different temperature requirements can be kept in the best-quality condition from the point of supply to the point of consumption throughout the processes of storage and distribution along the food supply chain (Kuo and Chen 2010). Seafarers can thus be assured that the products they order will be received freshly, safely and on time.

Broadly speaking, ships' captains send their requisitions and orders to LSCs to obtain the required amount of food. The purchase manager and the assistant purchase manager usually search advertisements, websites (ShipNet or ShipLink) and port agents for possible supplies. When vessels arrive at port, suppliers need to arrange for the food to be on board within $12 \mathrm{~h}$ between the estimated time of arrival (ETA) and the estimated time of departure (ETD). Vessels report regularly to the purchase department about the quality and quantity of supplies and provide feedback on the performance and the quality of the products they received. This information goes into the supplier performance record. The above procedures, as shown in Fig. 3, are a critical process in the food supply to seafarers.

We would like to stress that although this case study is not based upon observations across a wide range of random samples, we have made every effort to reduce biases. Large random samples have strong explanatory and statistical power, but the case study is sometimes appropriate or relevant as a research method. In this study, the case study is used to verify the analysis framework and results. Strategically chosen interviewees may greatly add to the generalisability of the case study. However, bias cannot be fully eliminated. One limitation due to a limited sample size is that all the sample data come from one district or region. Nevertheless, this study provides a foundation for further research.

\section{Shortcomings of adoption and implementation}

In the maritime industry, food issues were first addressed by the ILO Food and Catering (Ships' Crews) Convention 1946 (No. 68) and the Certification of Ships' Cooks Convention 1946 (No. 69). Issues regarding seafarers' food and catering were amended, drafted and signed in the Maritime Labour Convention (MLC) in 2006. The survey respondents expressed that the ILO maintains the current standards of international maritime labour conventions and recommendations and that the fundamental principles can be realised in other International Labour Conventions. Issues of seafarers are always addressed at the international level (ILO, 1946).

Food and catering are organised under Regulation 3.2. The survey respondents agreed that seafarers have access to good quality food and drinking water given the regulated hygienic conditions. To a large extent, the general standards of the international mandatory requirements shown in section A are upheld. The MLC provides wellsupported, structural and organised legal documents to improve compliance with international requirements. To facilitate the implementation of the mandatory requirements (i.e., the Regulations and the Code), the ratifying countries have established close 


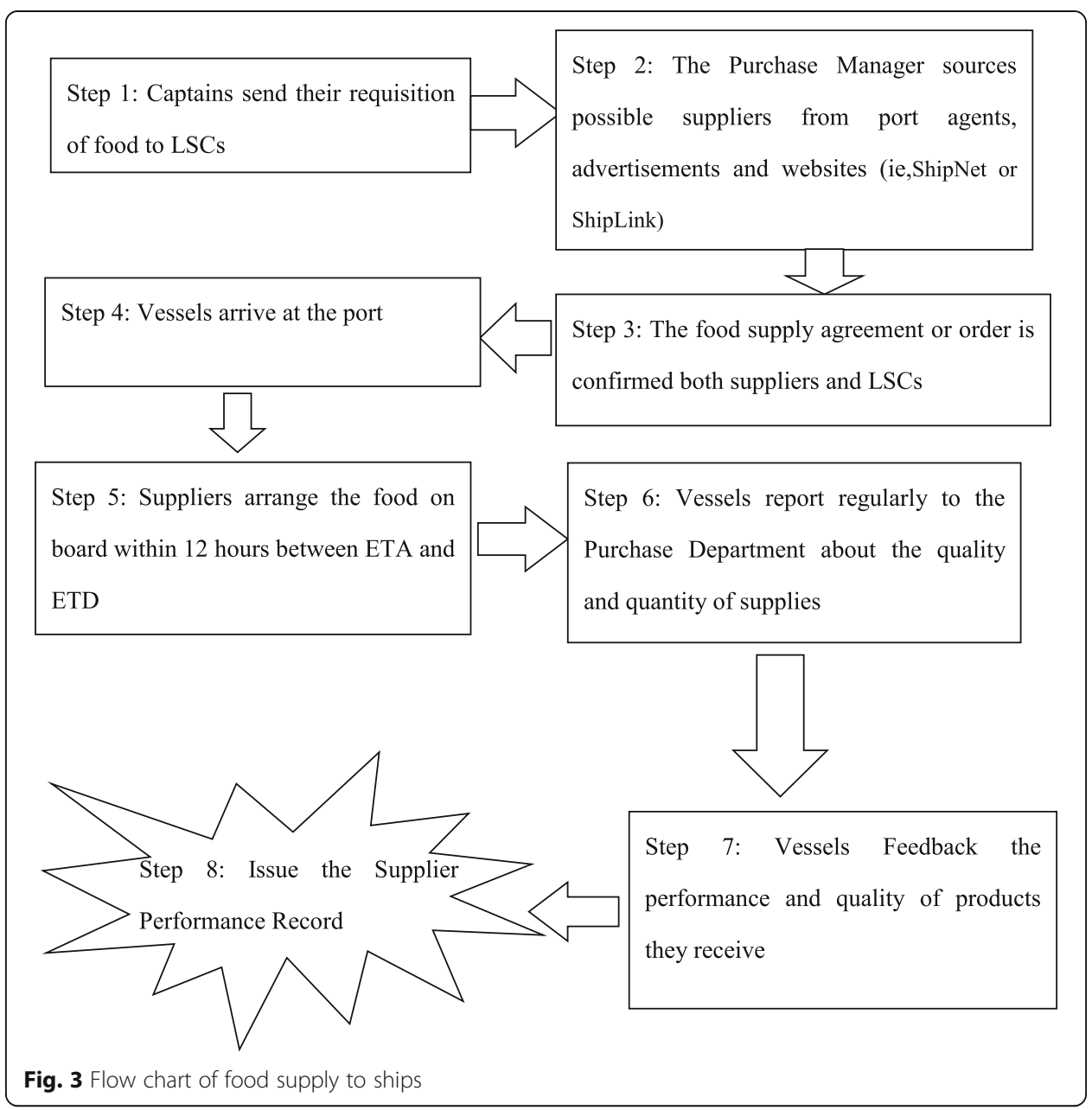

relationships with the designated authorities. The survey respondents indicated that they have positive views of maritime stakeholders' ability to obtain key information (i.e., ILO Regulations and the Code) without time and spatial restrictions because of technological advancements.

However, the MLC performed ineffectively in initial implementation, and the Regulations and the Code were delayed for almost 8 years before formulation and recognition in the maritime industry. The MLC was finally implemented on 20 August 2013. Although the MLC is one of the four pillars (MLC, SOLAS, STCW and MARPOL) of maritime policy, the survey respondents expressed that seafarers' food and catering is a problem to solve rather than an opportunity to innovate. We conclude that the MLC is a rather weak convention that has not materially changed life at sea.

Most of the respondents reported that technology, outbound logistics, procurement procedures, qualified personnel and staff training are the critical elements of food supply chain operations. The legal documents and the Code can be amended through the simplified procedure set out in Article XV of the Convention. In principle, the regulations should be fully implemented. In practice, a country can carry out 'substantially equivalent' regulations that they declare upon ratification. Accordingly, the survey respondents indicated that there is misalignment in the implementation and promulgation of seafarers' food and catering instruments in different global regions. The 
convention also does not address the interpretation of what can be termed 'good nutritious food'. The more important parts of the convention are shown and listed in the non-mandatory section B. Thus, the extent to which seafarers' food and catering measures can be implemented in ship operations is mainly determined by the attitude of ship operators. As indicated in the survey results, the attitude of ship operators towards seafarers' food is essential in improving seafarer working conditions. Although ship operators demonstrate due diligence in improving the food supply, seafarers have continued to experience exposure to biological agents resulting from poor food hygiene, contaminated food or drinking water, dirty or wet linen, inappropriate personal hygiene, unhygienic treatment in the ship's hospital and the spread of bacteria and viruses like influenza (ILO, 2015). The survey respondents reported that poor health conditions adversely affect seafarers' performance and behaviour. Various human errors can occur, including mistakes, fires, occupational accidents and collisions/groundings (Orosa and Oliverira, 2012).

The enforcement of the MLC Regulations and Code appears to have maintained relatively hygienic conditions for seafarers and provided good quality food and drinking water. The MLC has been in effect in the maritime industry for almost 2 years. So far, the convention has been ratified by 77 countries representing $91 \%$ of global shipping (ILO, 2015). The survey respondents stated that the MLC Regulation and Code should be adopted by all countries. Because of financial considerations, some governments are unwilling to support and allocate resources to improve seafarers' working conditions. Furthermore, ships are registered under flags of convenience to avoid regulations and reduce operating costs of the owners' countries. According to the ILO (2015), when working aboard ships flagged to states that do not 'exercise effective jurisdiction and control' over their ships, 'seafarers often have to work under unacceptable conditions, to the detriment of their well-being, health and safety and the safety of the ships on which they work'. However, most survey respondents held a different view on this matter. A Flag of Convenience (FOC) will not necessarily lead to poor quality in all aspects of crew management, including food. Finally, most survey respondents stated that seafarers perceived significant improvements in working conditions under seafarers' trade unions.

\section{Conclusions}

LSCs are coping with the demand for a wider range of high-quality food for seafarers. Meeting this demand is one way to retain good seafarers in LSCs. Seafarers are not only great assets to LSCs but also enhance ship safety levels. Although the ILO has worked to improve the food supply of seafarers by updating a series of rules and regulations, the adoption and implementation of effective food supply chains on board seems to be an obstacle to progress. Compared with tramp shipping, LSCs face a less serious food supply problem because liner shipping operates on fixed routes with fixed schedules. LSCs are most likely familiar with the functions of port and food suppliers along the ship itinerary. Yet LSCs are now facing a food supply problem, notably in the Southeast Asian region. There are many small ports in this region with few available food suppliers for LSCs. The procurement of food is determined in part by the duration and type of ship itinerary. 
Our study has two implications. From a theoretical perspective, it presents a proposed framework for performing flexible, punctual and responsive food supply. The framework will be helpful to facilitate food supply for LSCs and further evaluate associated supply chains. We use value chain analysis as a fundamental theoretical framework to evaluate the importance of the food supply chain for ships. The results clearly indicate that advanced technology, comprehensive procurement procedures, qualified personnel, extensive outbound logistics (i.e., distribution) networks for on-board food delivery and sound training programmes for staff on food quality and safety are core elements of the food supply chain, and can enhance the quality of food for seafarers. This study also has a managerial implication: the role of the ship procurement department should include the strategic position of LSCs in forthcoming years.

Although we carried out only a small scale of study with 11 survey respondents, their insights provide a useful reference for LSCs to evaluate their food supply chains to help improve food provisions for seafarers. This research can also be extended to cover the effects of ship automation on the food supply chain on board. Furthermore, this study provides a framework for further research on other regions across the globe by interviewing seafarers and crewing companies from different parts of the world. Such work would significantly enhance the overall quality of the food supply chain and redefine key food supply chain performance indicators at both the international and regional levels. The concept of food safety management is extremely important for food supply chain performance indicators, and should be highlighted in future research.

\section{Acknowledgements}

The paper is supported by G-YBH9 which is funded by the Hong Kong Polytechnic University. The funding body has no role in the design of the study and collection, analysis, and interpretation of data and writing the manuscript. This paper is a substantially updated and expanded version of a paper entitled "Food supply chain of a liner shipping company: A case study", presented at Proceedings of IFSPA 2012, Hong Kong, pp. 111-122.

\section{Authors' contributions}

YL wrote the manuscript. TLY edited and revised the manuscript. YL collected the data and TLY analysed the data. Both authors read and approved the final manuscript.

Competing interests

The authors declare that they have no competing interests.

\section{Publisher's Note}

Springer Nature remains neutral with regard to jurisdictional claims in published maps and institutional affiliations.

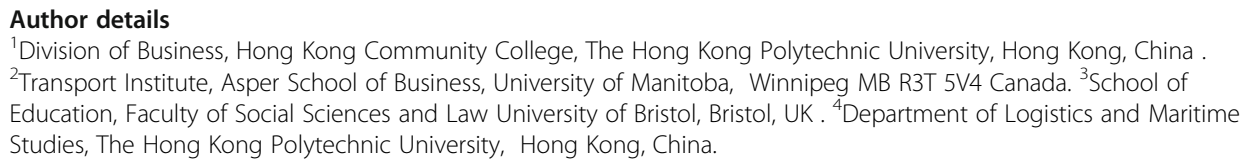

References

An M, Noh Y (2009) Airline customer satisfaction and loyalty: impact of in-flight service quality. Serv Bus 3:293-307

Associates KS (1993) Efficient consumer response: enhancing consumer value in the grocery industry. In: Food marketing institute. DC, Washington

Byran R, Brian A (1999) Food thermophysical property models. International Communications in Heat and Mass Transfer 26(5):627-636

Campbell D, Stonehouse D, Houston B (2002) Business strategy: an introduction, Second edn. Elsevier, USA

Dani S, Deep A (2010) Fragile food supply chains: reacting to risks. Int J Logistics: Research \& Application 13(5):395-410

Doumbia-Henry C (2003) Current maritime labour law issues - an internationally uniform identity document for seafarers. WMU J Marit Aff 2(2):129-148

lijima M, Komatsu S, Katoh S (1996) Hybrid just-in-time logistics systems and information networks for effective management in perishable food industries. Int J Prod Econ 44(1-2):97-103 
ILO. (1946). C68 Food and Catering (Ships' Crews) Convention

ILO (1999) Decent work. Report of the director-general. International Labor Conference, 87th Geneva:4

ILO. (2014). Guidelines on the training of ships' cooks, Geneva

ILO. (2015). http://www.ilo.org/global/about-the-ilo/lang\%2D-en/index.htm, Accessed May 1, 2015

Keiser J, DeMicco FJ, Cobanoglu C, Grimes RN (2008) Analyzing and controlling foodservice costs: a managerial and technological approach. Person/Prentice-Hall. Upper Saddle River, N.J

Kuo JC, Chen MC (2010) Developing an advanced multi-temperature joint distribution system for the food cold chain. Food Control 21(4):559-566

Lau YY, Yip TL (2010) Inbound logistics for liner shipping companies. Seaview 89:3-7

Lobrigo E, Pawlik T (2015) Maritime policy and the seafaring labor market. WMU J Marit Aff 14(1):123-139

Lu Y, Gao Y, Cao Z, Cui J, Dong Z, Tan Y, Xu Y (2010) A study of health effects of long-distance ocean voyages on seamen using a data classification approach. BMC Med Inform Decis Mak 10(13):1-20

Lynch R (2003) Corporate strategy, 3rd edn. Financial Times, Prentice Hall

McConnell ML (2011) The maritime labour convention, 2006 - reflections on challenges for flag state implementation. WMU J Marit Aff 10(2):127-141

McWilliams M (2008) Food Fundamentals. Pearson/Prentice-Hall, New Jersey

Milde PC (2011) The maritime labor convention 2006: an instrument to improve social responsibility in the cruise industry. Springer Fachmedien Wiesbaden GmbH, Gabler Verlag

Mohsen A (2005) A new method to assess the quality degradation of food products during storage. J Food Eng 75(4):560-564

Montanari R (2008) Cold chain tracking: a managerial perspective. Trends in Food Science \& Technology 19(8):425-431

Muller A, Steinhart H (2006) Recent developments in instrumental analysis for food quality. Food Chem 101(3):1136-1144

Myznikov IL, Makhrov MG, Rogovanov D (2000) Morbidity in seamen during long voyages according to the results of long-term studies. Voen Med Zh 321(7):60-63

Officer of the Watch (2012). Seafarer's Health \& Lifestyle. https://officerofthewatch.com/2012/04/22/seafarers-healthlifestyle/, Accessed August 22017

Orosa J, Oliverira A (2012) Case study of safe working conditions in Spanish merchant ships. Polish Maritime Research 19(2):43-48

Ovca A, Jevsnik M (2009) Maintaining a cold chain from purchase to the home and at home: consumer opinions. Food Control 20(2):167-172

Pathania-Jian G (2001) Global parents, local partners: a value-chain analysis of collaborative strategies of media firms in India. Journal of Media Economics 14(3):169-187

Porter ME (1985) Competitive advantage: creating and sustaining superior performance. Free Press, New York

Porter ME (1990) The competitive advantage of nations. Free Press, New York

Protasov W, Slezinger VM, Antiukhova MP (1996) The dynamics of anti-influenza immunity in sailors of the Baltic fleet. Voen Med Zh 317(9):33-34

Robert H, Marek K, Geoff F (1998) Food Transportation, Blackie Academic \& Professional. London, New York

Rodrigue, JP. Craig, M. (2009). The cold chain. In: Rodrigue P., Comtois C. Slack B. (2009). The Geography of Transport System. Chapter 5. Routledge: New York

Roth AV, Tsay AA, Pullman ME, Gray JV (2008) Unraveling the food supply chain: strategic insights from China and the 2007 recalls. The Journal of Supply Chain Management 44(1):22-39

Van Der Vorst JGAJ, Beulens AJM (1999) A research model for the redesign of food supply chains. International Journal of Logistics: Research \& Application 2(2):161-174

Verbic M (2006) Discussing the parameters of preservation of perishable goods in a cold logistic chain model. Appl Econ 38(2):137-147

\section{Submit your manuscript to a SpringerOpen ${ }^{\circ}$ journal and benefit from:}

- Convenient online submission

- Rigorous peer review

Open access: articles freely available online

- High visibility within the field

- Retaining the copyright to your article 